九州大学学術情報リポジトリ

Kyushu University Institutional Repository

\title{
Study on Management of Provincial Forest in Korea
}

Choi, Soo Im

Department of Forest Resources, Sunchon National University

Kang, Hag Mo

Department of Forest Environmental Science, Chonbuk National University

Sato, Noriko

Laboratory of Forest Policy, Division of Forest Environment and Management Sciences, Department of Agro-environmental Sciences, Faculty of Agriculture, Kyushu University

Kim, Hyun

Jeonbuk Forest Environment Research Institute

https://doi.org/10.5109/25212

出版情報：九州大学大学院農学研究院紀要. 57 (2)，pp.499-505，2012-09-20. Faculty of Agriculture, Kyushu University

バージョン :

権利関係 : 


\title{
Study on Management of Provincial Forest in Korea
}

\author{
Soo Im CHOI ${ }^{1}$, Hag Mo KANG ${ }^{2}$, Noriko SATO and Hyun $\mathrm{KIM}^{3 *}$ \\ Laboratory of Forest Policy, Division of Forest Environment and Management Sciences, \\ Department of Agro-environmental Sciences, Faculty of Agriculture, \\ Kyushu University, Fukuoka 812-8581, Japan \\ (Received April 27, 2012 and accepted May 10, 2012)
}

\begin{abstract}
While Korean provincial forest is 154,000 ha corresponding to $2.4 \%$ of total forest area, 6,380,000 ha, continuous investment has been given to formation of forest management basis such as forest road construction and forestation and it helps local economy via lending, permission for use, and paid or non-paid donation of forest product to local residents In addition, although it seems that functions and roles of provincial forest such as absorption of demand for forest leisure will be increased further, there is actually few direct study on management form and use of provincial forest Thus, management and utilization forms were investigated against 5 provincial forests in the whole country As results, it was found that average annual revenue of 4 provinces excluding 1,500 million won from sale of provincial forest in Chungnam was 92 million won and the mean estimated expenditures was 2,838 million won Although the area of lending and use permission of national forest accounted for $4.5 \%$ of total area of national forest, the subjected 5 provinces accounted for $3.3 \%$ The average earning of the 5 provinces from their provincial property was 51.61 million won, which was very low level, accounting for $1.8 \%$ of the average annual expenditure of 5 provinces, 2,838 million won Therefore, it was considered that for future development of provincial forest, positive efforts for marketing the thinned wood and byproducts for securing estimated revenues that was markedly lower than the annual expenditures would be necessary in addition to intensive use of provincial forest by expanding further lending and use permission to their residents Finally, in order to suggest developmental measures for provincial forest of each province concretely it was identified that there was a need for analysis on multilateral aspects such as forest type, long term management goal, and environmental conditions by provincial forests.
\end{abstract}

Keywords: forest type, forest projects, Korea, provincial forest, provincial property

\section{INTRODUCTION}

Possession type of forest is divided largely into national forest and civil owned forest and the national forest is classified into forest under jurisdiction of Forest Service and forest under other authorities The civil owned forest is divided into public forest and private forest and the public forest is classified into provincial forest administered by each province and county forest administered by local governments such as city and county.

Although the provincial forest, 154,000 ha, accounted for low level, $2.4 \%$ of total forest area 6.38 million ha (Forest Service, 2008a), it has formed forest management basis such as forest road installation and forestation with continuous investment In addition, it helps local economy via lending, permission for use, and paid or non-paid donation of forest product to local residents and it seems that functions and roles of provincial forest such as absorption of fast increasing demand for forest leisure as well as nature lessons, leisure, and forest byproduct production, will be increased further Besides most of studies on administration and management of provincial forest were performed on collection of forest

\footnotetext{
1 Department of Forest Resources, Sunchon National University, Suncheon, 540-742, Korea

${ }^{2}$ Department of Forest Environmental Science, Chonbuk National University, Chonju, 561-756, Korea

${ }^{3}$ Jeonbuk Forest Environment Research Institute, Jinan-gun, 561-756, Korea

* Corresponding author (E-mail: kh4548@korea.kr)
}

products made in the provincial forest (Forest Service, 2008b; Park et al., 1987a; Park et al., 1987b), drawing up of forest function classification diagram of public forest, forest function assessment of public forest (Kwon et al., 2008), and development of forest administration system using geographic information system (Jeon, 2002) and direct study on management forms and uses of provincial forest was scarce actually Therefore, the purpose of this study is to grasp problems and seek future direction for development in management of provincial forest by investigating their management and use forms against 5 provincial forests in the whole country.

\section{MATERIALS AND METHODS}

The field investigation was performed via interview with persons responsible for them against 5 provincial forests of 5 provinces such as Gyeonggi, Gangwon, Chungnam, Jeonbuk, and Gyeongnam among 8 provinces in the whole Korea The field survey was conducted for 4 months from March to June, 2009, of which contents included status of area and accumulation of provincial forest, wood accumulation by age groups, status of revenue and expenditure of the provincial forest, status of lending and use permission of provincial property, earning status of provincial property, and major forest projects of provincial forest Data were compared and analyzed by provinces. 


\section{RESULTS AND DISCUSSIONS}

\section{Area and accumulation status of provincial forest} Area and forest tree accumulation of provincial forest

For area and forest tree accumulation of provincial forests of 5 provinces targeted among total 8 provinces excluding Jeju-do, it was found that average area of the whole provincial forests was about 7 million ha and Gangwon-do has the largest area as 1.37 million ha, followed by Gyeongnam with 0.71 million ha, Gyeonggi with 0.53 million ha, Jeonbuk with 0.45 million ha, and Chungnam with 0.44 million ha It was found also that the average area of provincial forests was 19,000 ha and Gyeonggi had the largest area as 31,000 ha, followed by Gangwon with 29,000 ha and Gyeongnam with 16,000 ha Jeonbuk and Chungnam had 11,000 ha of average area respectively For the ratio taken by provincial forest in the whole forest area of the provinces, it was shown that Gyeonggi had the greatest ratio as 5.9\% and the ratio of other 4 provinces was $2.1 \sim 2.5 \%$ In addition, the average forest tree accumulation of total provinces was 73 million and among them, Gangwon had the largest accumulation as 168 million $\mathrm{m}^{3}$, followed by Gyeongnam with 63 million and Jeonbuk with 47 million $\mathrm{m}^{3}$ (Forest Service, 2008a) The average tree accumulation of each provincial forest was 2.1 million $\mathrm{m}^{3}$ and Gyeonggi had the most value with 3.4 million $\mathrm{m}^{3}$, followed by Gangwon with 3.0 million $\mathrm{m}^{3}$ (Table 1 ).

Forest tree accumulation of provincial forest by age groups

The average forest tree accumulation per ha of targeted 5 provinces was $108 \mathrm{~m}^{3}$, higher than $98 \mathrm{~m}^{3}$ of the whole country It was found that Gyeongnam had the highest forest tree accumulation per ha as $121 \mathrm{~m}^{3}$, followed by Gyeonggi with $110 \mathrm{~m}^{3}$, Gangwon with $104 \mathrm{~m}^{3}$, and Chungnam with $101 \mathrm{~m}^{3}$ By age groups, while for 5 provinces, the ratio of over 30 year old trees was more than $75 \%$, the average of the whole country was 58\% It was shown that among the targeted provinces, Gyeonggi had the highest ratio of over 30 year old trees as $86 \%$, followed by Gyeongnam with 85\%, Chungnam with $71 \%$, Gangwon with 66\%, and Jeonbuk with 61\% (Table 2).

\section{Status of administration and management of pro- vincial forest}

Revenue and expenditure of provincial forest

For the revenue and expenditure status of provincial forest of targeted 5 province, it was found that the aver-

Table 1. Area and forest tree accumulation of provincial forest

\begin{tabular}{|c|c|c|c|c|c|c|}
\hline Classification & $\begin{array}{c}\text { Forest area } \\
\text { of the whole } \\
\text { province } \\
(10,000 \text { ha) }\end{array}$ & $\begin{array}{c}\text { Area of } \\
\text { provincial } \\
\text { forest } \\
(10,000 \text { ha })\end{array}$ & $\begin{array}{l}\text { Total forest } \\
\text { area of provincial } \\
\text { forest /province } \\
\text { (\%) }\end{array}$ & $\begin{array}{c}\text { Tree accumulation } \\
\text { of total } \\
\text { province } \\
\left(\text { million } \mathrm{m}^{3}\right)\end{array}$ & $\begin{array}{l}\text { Tree accumulation } \\
\text { of provincial forest } \\
\quad\left(\text { million } \mathrm{m}^{3}\right)\end{array}$ & $\begin{array}{c}\text { Total forest tree } \\
\text { accumulation of } \\
\text { provincial forest /province } \\
(\%)\end{array}$ \\
\hline Total & 349.4 & 9.7 & 2.8 & 363.1 & 10.4 & 2.9 \\
\hline Average & 69.9 & 1.9 & 2.8 & 72.6 & 2.1 & 2.9 \\
\hline Gyeonggi & 52.9 & 3.1 & 5.9 & 45.9 & 3.4 & 7.4 \\
\hline Gangwon & 136.9 & 2.9 & 2.1 & 168.0 & 3.0 & 1.8 \\
\hline Chungnam & 44.0 & 1.0 & 2.3 & 39.1 & 1.0 & 2.6 \\
\hline Jeonbuk & 44.8 & 1.1 & 2.5 & 47.1 & 1.0 & 2.1 \\
\hline Gyeongnam & 70.8 & 1.6 & 2.3 & 63.1 & 1.9 & 3.0 \\
\hline
\end{tabular}

Note: Area and tree accumulation of nationwide forest were 6.38 million ha and 6.24 million $\mathrm{m}^{3}$, respectively.

Table 2. Forest tree accumulation of provincial forest by age groups

(Unit: $10,000 \mathrm{~m}^{3}, \%$ )

\begin{tabular}{|c|c|c|c|c|c|c|c|}
\hline Classification & $\mathrm{m}^{3} / \mathrm{ha}$ & Total & II age group & III age group & IV age group & $\mathrm{V}$ age group & VI age group \\
\hline Whole country & 98 & $\begin{array}{c}62,440 \\
(100)\end{array}$ & $\begin{array}{c}5,712 \\
(9)\end{array}$ & $\begin{array}{c}20,296 \\
(33)\end{array}$ & $\begin{array}{c}24,231 \\
(39)\end{array}$ & $\begin{array}{c}8,899 \\
(14)\end{array}$ & $\begin{array}{c}3,302 \\
(5)\end{array}$ \\
\hline Total & 108 & $\begin{array}{l}1,044 \\
(100)\end{array}$ & $\begin{array}{l}38 \\
(4)\end{array}$ & $\begin{array}{l}214 \\
(21)\end{array}$ & $\begin{array}{l}484 \\
(46)\end{array}$ & $\begin{array}{l}262 \\
(25)\end{array}$ & $\begin{array}{l}46 \\
(4)\end{array}$ \\
\hline Gyeonggi & 110 & $\begin{array}{c}342 \\
(100)\end{array}$ & $\begin{array}{c}5 \\
(2)\end{array}$ & $\begin{array}{c}44 \\
(13)\end{array}$ & $\begin{array}{l}164 \\
(48)\end{array}$ & $\begin{array}{l}115 \\
(34)\end{array}$ & $\begin{array}{l}14 \\
(4)\end{array}$ \\
\hline Gangwon & 104 & $\begin{array}{c}302 \\
(100)\end{array}$ & $\begin{array}{l}26 \\
(9)\end{array}$ & $\begin{array}{c}77 \\
(25)\end{array}$ & $\begin{array}{l}134 \\
(44)\end{array}$ & $\begin{array}{c}45 \\
(15)\end{array}$ & $\begin{array}{l}20 \\
(7)\end{array}$ \\
\hline Chungnam & 101 & $\begin{array}{c}101 \\
(100)\end{array}$ & $\begin{array}{c}3 \\
(3)\end{array}$ & $\begin{array}{c}26 \\
(26)\end{array}$ & $\begin{array}{c}48 \\
(48)\end{array}$ & $\begin{array}{c}13 \\
(13)\end{array}$ & $\begin{array}{c}11 \\
(10)\end{array}$ \\
\hline Jeonbuk & 95 & $\begin{array}{c}105 \\
(100)\end{array}$ & $\begin{array}{c}2 \\
(2)\end{array}$ & $\begin{array}{c}39 \\
(37)\end{array}$ & $\begin{array}{c}50 \\
(48)\end{array}$ & $\begin{array}{c}14 \\
(13)\end{array}$ & - \\
\hline Gyeongnam & 121 & $\begin{array}{c}194 \\
(100)\end{array}$ & $\begin{array}{c}2 \\
(1)\end{array}$ & $\begin{array}{c}28 \\
(14)\end{array}$ & $\begin{array}{c}88 \\
(45)\end{array}$ & $\begin{array}{c}75 \\
(39)\end{array}$ & $\begin{array}{c}1 \\
(1)\end{array}$ \\
\hline
\end{tabular}

Note: The value in ( ) is the component ratio. 
age revenue of 5 provinces was 373 million won, but the average revenue of 4 provinces excluding 1,500 million won from selling provincial forest of Chungnam was 92 million won Contents of the revenue consisted of 172 million of forest byproducts, 120 million won of rental income, and 72 million won of collection of province owned forest products

In addition, for the expenditure it was found that the average expenditure of 5 provinces was 2,838 million won, 7 times more than the revenue, and Gangwon had the greatest estimated expenditure as 5,302 million won, followed by Gyeonggi with 4,855 million won, Gyeongnam with 1,582 million won, and Chungnam with 1,397 million won Among the major contents of the expenditure, the forest resource growing was the most as $44 \%$, followed by formation and complement project of leisure facilities with $20 \%$ and basis establishment of provincial forest with 19\% For reference, the targeted 5 provinces had formed or are forming 1 3 sites of natural leisure facility with their provincial forest and especially Gangwon was operating a hunting site (Gyeonggi-do Forestry Environment Research Institute, 2009; Gangwon-do Forest Development Research Center, 2008; Chungnam Forestry Environment Research Institute, 2009; Jeonbuk Forestry Environment Research Institute, 2009; Gyeongnam Forestry Environment Research Institute, 2009).
Status of lending and use permission of provincial property

For the number of cases and their contents relating to lending and use permission of national forest (including profit-sharing forest), it was shown that their total number of cases was 11,793 and common, public, and industry purpose took their major part (Forest service, 2008a) For the status of lending and use permission of provincial property in the targeted provinces, it was known that total number of use permission was 713 and average number of each province was 143 For the number of permission by provinces it was found that Chungnam had the largest number as 395, followed by Gyeonggi with 152, Gangwon with 123, Jeonbuk with 36, and Gyeongnam with 5 Their contents of permission had some differences by regions, but residence took the largest part as $32 \%$, followed by farming with $15 \%$, common and public with $6 \%$, and military installation with $5 \%$ (Gyeonggi-do Forestry Environment Research Institute, 2008; Gangwon-do Forest Development Research Center, 2008; Chungnam Forestry Environment Research Institute, 2009; Jeonbuk Forestry Environment Research Institute, 2009; Gyeongnam Forestry Environment Research Institute, 2009) By regions, it was found that military installation and steel tower in Gyeonggi, common and public and industry in Gangwon, residence and farming in Chungnam, and collection of forest products and farming in Jeonbuk took relatively larger part, suggesting there were some differences in the contents of

Table 3. Revenue and expenditure of provincial forest

(Unit: Million won, \%)

\begin{tabular}{|c|c|c|c|c|c|c|c|c|c|c|}
\hline \multirow[t]{2}{*}{ Classification } & \multicolumn{5}{|c|}{ Revenue } & \multicolumn{5}{|c|}{ Expenditure } \\
\hline & Total & $\begin{array}{l}\text { Property } \\
\text { selling of } \\
\text { provincial } \\
\text { forest }\end{array}$ & $\begin{array}{c}\text { Forest } \\
\text { byproducts }\end{array}$ & $\begin{array}{l}\text { Rental } \\
\text { income }\end{array}$ & $\begin{array}{c}\text { Collection } \\
\text { of province } \\
\text { owned } \\
\text { forest } \\
\text { products }\end{array}$ & Total & $\begin{array}{l}\text { Developing } \\
\text { forest } \\
\text { resources }\end{array}$ & $\begin{array}{l}\text { Formation } \\
\text { and } \\
\text { complement } \\
\text { of leisure } \\
\text { facility }\end{array}$ & $\begin{array}{l}\text { Forming a } \\
\text { basis of } \\
\text { provincial } \\
\text { forest }\end{array}$ & Others \\
\hline Total & $\begin{array}{l}1,866 \\
(100)\end{array}$ & $\begin{array}{c}1,500 \\
(80)\end{array}$ & $\begin{array}{l}172 \\
(9)\end{array}$ & $\begin{array}{l}120 \\
(6)\end{array}$ & $\begin{array}{l}72 \\
(4)\end{array}$ & $\begin{array}{c}14,192 \\
(100)\end{array}$ & $\begin{array}{c}6,298 \\
(44)\end{array}$ & $\begin{array}{c}2,831 \\
(20)\end{array}$ & $\begin{array}{c}2,691 \\
(19)\end{array}$ & $\begin{array}{c}2,372 \\
(17)\end{array}$ \\
\hline Average & 373 & 300 & 34 & 24 & 14 & 2,838 & 1,260 & 566 & 538 & 474 \\
\hline Gyeonggi & 113 & - & 2 & 73 & 38 & $\begin{array}{l}4,855 \\
(100)\end{array}$ & $\begin{array}{c}1,697 \\
(35)\end{array}$ & $\begin{array}{c}2,130 \\
(44)\end{array}$ & $\begin{array}{l}873 \\
(18)\end{array}$ & $\begin{array}{l}155 \\
(3)\end{array}$ \\
\hline Gangwon & 214 & - & 170 & 37 & 5 & $\begin{array}{l}5,302 \\
(100)\end{array}$ & $\begin{array}{c}1,478 \\
(28)\end{array}$ & $\begin{array}{l}524 \\
(10)\end{array}$ & $\begin{array}{l}1,083 \\
(20)\end{array}$ & $\begin{array}{c}2,217 \\
(42)\end{array}$ \\
\hline Chungnam & 1,500 & 1,500 & - & - & - & $\begin{array}{l}1,397 \\
(100)\end{array}$ & $\begin{array}{l}818 \\
(59)\end{array}$ & - & $\begin{array}{l}579 \\
(41)\end{array}$ & - \\
\hline Jeonbuk & 18 & - & - & 10 & 8 & $\begin{array}{l}1,056 \\
(100)\end{array}$ & $\begin{array}{l}979 \\
(93)\end{array}$ & $\begin{array}{l}77 \\
(7)\end{array}$ & - & - \\
\hline Gyeongnam & 21 & - & - & - & 21 & $\begin{array}{l}1,582 \\
(100)\end{array}$ & $\begin{array}{l}1,326 \\
(84)\end{array}$ & $\begin{array}{l}100 \\
(6)\end{array}$ & $\begin{array}{l}156 \\
(10)\end{array}$ & - \\
\hline
\end{tabular}

Note: 1. Collection of province owned forest products of Gyeonggi includes Gorosoe fluid and pine nuts and forest byproduct is forest tree selling.

2. Forest byproducts in Gangwon's revenue are 140 million won from selling wood materials and 30 million won from young plants.

3. Other in expenditure of Gangwon is construction of training facility.

4. Basis forming project of provincial forest mainly includes projects for forest road and erosion control works and forest resource growing projects include mainly forestation, forest fire prevention, and control of forest pest.

5. Collection of province owned forest products of Gyeongnam is Gorosoe fluid.

6 . The value in ( ) is the component ratio. 
permission by regions

First, for the area contents of lending and use permission of national forest, it was found that among total area, 67,190 ha, profit-sharing forest and common and public area took the largest part as $38 \%$ and $32 \%$ but the permission area accounted for $4.5 \%$ of total area of national forest, 1,509,163 ha The total permission area (including profit-sharing forest) of the targeted 5 provinces was 3,203 ha, which accounted for 3.3\% of total area of provincial forest, 97,000 ha, showing a level slightly lower than that of national forest In addition when excluding the profit sharing forest of Jeonbuk, the total

Table 4. Number of cases for lending and use permission of provincial property

(Unit: No of cases, \%)

\begin{tabular}{|c|c|c|c|c|c|c|c|c|c|c|c|c|c|}
\hline Classification & Total & Residence & Farming & $\begin{array}{c}\text { Common, } \\
\text { public }\end{array}$ & $\begin{array}{c}\text { Military } \\
\text { installation }\end{array}$ & Industry & $\begin{array}{l}\text { Steel } \\
\text { tower }\end{array}$ & $\begin{array}{l}\text { Collection of } \\
\text { forest } \\
\text { products }\end{array}$ & $\begin{array}{l}\text { Cattle } \\
\text { raising }\end{array}$ & Mining & Leisure & Forestation & Others \\
\hline $\begin{array}{c}\text { National } \\
\text { forest }\end{array}$ & $\begin{array}{c}12,139 \\
(100)\end{array}$ & - & - & $\begin{array}{c}2,348 \\
(19)\end{array}$ & - & $\begin{array}{c}2,975 \\
(25)\end{array}$ & - & - & $\begin{array}{l}221 \\
(2)\end{array}$ & $\begin{array}{l}254 \\
(2)\end{array}$ & - & $\begin{array}{l}176 \\
(1)\end{array}$ & $\begin{array}{c}6,165 \\
(51)\end{array}$ \\
\hline Total & $\begin{array}{c}713 \\
(100)\end{array}$ & $\begin{array}{l}227 \\
(32)\end{array}$ & $\begin{array}{l}109 \\
(15)\end{array}$ & $\begin{array}{l}42 \\
(6)\end{array}$ & $\begin{array}{l}39 \\
(5)\end{array}$ & $\begin{array}{l}23 \\
(3)\end{array}$ & $\begin{array}{l}19 \\
(3)\end{array}$ & $\begin{array}{l}18 \\
(3)\end{array}$ & $\begin{array}{c}7 \\
(1)\end{array}$ & 4 & 3 & 1 & $\begin{array}{l}222 \\
(31)\end{array}$ \\
\hline Average & 143 & 45 & 22 & 8 & 8 & 5 & 4 & 4 & 1 & - & - & - & 44 \\
\hline Gyeonggi & $\begin{array}{c}154 \\
(100)\end{array}$ & $\begin{array}{c}17 \\
(11)\end{array}$ & $\begin{array}{c}16 \\
(10)\end{array}$ & - & $\begin{array}{c}30 \\
(19)\end{array}$ & - & $\begin{array}{c}19 \\
(12)\end{array}$ & 1 & 1 & - & 1 & - & $\begin{array}{c}69 \\
(45)\end{array}$ \\
\hline Gangwon & $\begin{array}{c}123 \\
(100)\end{array}$ & $\begin{array}{c}6 \\
(5)\end{array}$ & $\begin{array}{c}20 \\
(16)\end{array}$ & $\begin{array}{c}42 \\
(34)\end{array}$ & $\begin{array}{c}9 \\
(7)\end{array}$ & $\begin{array}{c}23 \\
(19)\end{array}$ & - & - & $\begin{array}{c}3 \\
(2)\end{array}$ & $\begin{array}{c}3 \\
(2)\end{array}$ & - & $\begin{array}{c}1 \\
(1)\end{array}$ & $\begin{array}{c}17 \\
(14)\end{array}$ \\
\hline Chungnam & $\begin{array}{c}395 \\
(100)\end{array}$ & $\begin{array}{l}204 \\
(52)\end{array}$ & $\begin{array}{c}67 \\
(17)\end{array}$ & - & - & - & - & - & - & - & $\begin{array}{c}2 \\
(1)\end{array}$ & - & $\begin{array}{l}122 \\
(31)\end{array}$ \\
\hline Jeonbuk & $\begin{array}{c}36 \\
(100)\end{array}$ & - & $\begin{array}{c}6 \\
(17)\end{array}$ & - & - & - & - & $\begin{array}{c}12 \\
(33)\end{array}$ & $\begin{array}{c}3 \\
(8)\end{array}$ & $\begin{array}{c}1 \\
(3)\end{array}$ & - & - & $\begin{array}{c}14 \\
(39)\end{array}$ \\
\hline Gyeongnam & $\begin{array}{c}5 \\
(100)\end{array}$ & - & & - & - & - & - & $\begin{array}{c}5 \\
(100)\end{array}$ & - & - & - & - & - \\
\hline
\end{tabular}

Note: 1. Others of Gyeonggi refer to automatic rainfall alarming facility, land for installation, public road, and installation of electric poles.

2. Forest products of Jeonbuk include 3 cases of persimmons and 9 cases of Gorosoe fluid.

3. Forest products of Gyeongnam is Gorosoe fluid.

4. The value in ( ) is the component ratio.

Table 5. Area for lending and use permission of provincial property

(Unit: ha, \%)

\begin{tabular}{|c|c|c|c|c|c|c|c|c|c|c|c|c|c|c|}
\hline Classification & Total & $\begin{array}{c}\text { Profit- } \\
\text { sharing } \\
\text { forest }\end{array}$ & Leisure & Forestation & $\begin{array}{c}\text { Military } \\
\text { installation }\end{array}$ & Farming & $\begin{array}{c}\text { Common, } \\
\text { public }\end{array}$ & $\begin{array}{l}\text { Cattle } \\
\text { raising }\end{array}$ & $\begin{array}{c}\text { Collection } \\
\text { of forest } \\
\text { products }\end{array}$ & Residence & Industry & Mining & $\begin{array}{l}\text { Steel } \\
\text { tower }\end{array}$ & Others \\
\hline $\begin{array}{c}\text { National } \\
\text { forest }\end{array}$ & $\begin{array}{c}67,190 \\
(100)\end{array}$ & $\begin{array}{c}25,499 \\
(38)\end{array}$ & - & $\begin{array}{c}6,008 \\
(9)\end{array}$ & - & - & $\begin{array}{c}21,169 \\
(32)\end{array}$ & $\begin{array}{c}3,818 \\
(6)\end{array}$ & - & - & $\begin{array}{c}3,422 \\
(5)\end{array}$ & $\begin{array}{c}1,188 \\
(2)\end{array}$ & - & 6,086 \\
\hline Total & $\begin{array}{l}3,203 \\
(100)\end{array}$ & $\begin{array}{c}2,070 \\
(65)\end{array}$ & $\begin{array}{l}680 \\
(21)\end{array}$ & $\begin{array}{l}155 \\
(5)\end{array}$ & $\begin{array}{l}77 \\
(2)\end{array}$ & $\begin{array}{l}51 \\
(2)\end{array}$ & 32 & 21 & 8 & 7 & 6 & 1 & 1 & 94 \\
\hline Average & 641 & 414 & 136 & 31 & 15 & 10 & 6 & 4 & 2 & 1 & 1 & - & - & 19 \\
\hline Gyeonggi & $\begin{array}{c}70 \\
(100)\end{array}$ & - & 136 & - & $\begin{array}{c}52 \\
(74)\end{array}$ & 2 & - & 1 & $\begin{array}{c}8 \\
(11)\end{array}$ & 1 & - & - & 1 & 5 \\
\hline Gangwon & $\begin{array}{c}290 \\
(100)\end{array}$ & - & - & $\begin{array}{l}155 \\
(53)\end{array}$ & $\begin{array}{l}25 \\
(9)\end{array}$ & $\begin{array}{c}45 \\
(16)\end{array}$ & $\begin{array}{c}32 \\
(11)\end{array}$ & $\begin{array}{l}20 \\
(7)\end{array}$ & - & 1 & 6 & 1 & - & 5 \\
\hline Chungnam & $\begin{array}{c}713 \\
(100)\end{array}$ & - & - & - & - & 4 & - & - & $\begin{array}{c}358 \\
\text { plants }\end{array}$ & 5 & - & - & - & 24 \\
\hline Jeonbuk & 2,130 & $\begin{array}{c}2,070 \\
(97)\end{array}$ & $\begin{array}{l}680 \\
(95)\end{array}$ & - & - & - & - & - & - & - & & - & - & 60 \\
\hline Gyeongnam & $\begin{array}{l}11,537 \\
\text { plants }\end{array}$ & - & - & - & - & - & - & - & $\begin{array}{l}11,537 \\
\text { plants }\end{array}$ & - & - & - & - & - \\
\hline
\end{tabular}

Note: 1 . Collection of forest product of Gyeonggi is cultivation of cultivated mountain ginseng.

2. Collection of forest product of Chungnam is Gorosoe fluid, non-paid lending.

3. Profit sharing forest of Jeonbuk is possessed by paper manufacturing company (2,044 ha) and Forestry Association (26 ha).

4. Collection of forest product of Gyeongnam is Gorosoe fluid and 11,537 plants are not included in total.

5 . The value in ( ) is the component ratio. 
permission area of 5 provinces was 1,133 ha and the average permission area of each province excluding Jeonbuk was 268 ha (Gyeonggi-do Forestry Environment Research Institute, 2008; Gangwon-do Forest Development Research Center, 2008; Chungnam Forestry Environment Research Institute, 2009; Jeonbuk Forestry Environment Research Institute, 2009; Gyeongnam Forestry Environment Research Institute, 2009) It was shown that for the permission area by provinces, Jeonbuk had the largest area as 2,130 ha, followed by Chungnam with 713 ha, Gangwon with 290 ha, and Gyeonggi with 70 ha For the ratio of permission area to total area of each provincial forest, it was found that they were 19\% of Jeonbuk, $7 \%$ of Chungnam, 1\% of Gangwon, $0.2 \%$ of Gyeonggi, and none of Gyeongnam (Table 5)

Status of Earning and forest project from provincial property

First, the earning status using the provincial property may be largely classified into earning from forest products and earning from lending and use permission Total earning of the targeted 5 provinces was 258.06 million won, the average earning of each province was 51.61 million won, and Gyeonggi had the largest earning as 153.02 million won The earning levels of other 4 provinces were in 18.17 44.15 million won However, the average earning of the 5 provinces from their provincial property was 51.61 million won, which was very low level, accounting for $1.8 \%$ of the average annual expenditure of 5 provinces, 2,838 million won Concretely, in case of Gyeonggi, earning from lending and use permission accounted for $74 \%$, followed by earning from pine nuts and Gorosoe fluid In case of Gangwon, the earning from lending and use permission took the almost all, Chungnam had no earning from forest products, Jeonbuk had similar ratio between earning from forest products and lending and use permission, and Gyeongnam had no earning from lending

Table 6. Earning from provincial property

(Unit: 10 thousand won)

\begin{tabular}{|c|c|c|c|c|c|c|c|c|c|c|c|c|c|c|}
\hline \multirow[t]{2}{*}{ Classification } & \multirow[t]{2}{*}{ Total } & \multicolumn{4}{|c|}{ Earning from forest products } & \multicolumn{8}{|c|}{ Earning from lending and use permission } & \multirow[t]{2}{*}{ Others } \\
\hline & & $\begin{array}{c}\text { Gorosoe } \\
\text { fluid }\end{array}$ & $\begin{array}{l}\text { Pine } \\
\text { nuts }\end{array}$ & $\begin{array}{c}\text { Forest } \\
\text { tree } \\
\text { selling }\end{array}$ & Persimmon & Forestation & Residence & $\begin{array}{l}\text { Cattle } \\
\text { raising }\end{array}$ & Farming & Leisure & Industry & Building & Mining & \\
\hline Total & $\begin{array}{c}25,806 \\
(100)\end{array}$ & $\begin{array}{c}4,388 \\
(17)\end{array}$ & $\begin{array}{c}2,634 \\
(10)\end{array}$ & $\begin{array}{l}174 \\
(1)\end{array}$ & 113 & $\begin{array}{c}2,117 \\
(8)\end{array}$ & $\begin{array}{l}848 \\
(3)\end{array}$ & $\begin{array}{l}834 \\
(3)\end{array}$ & $\begin{array}{l}713 \\
(3)\end{array}$ & $\begin{array}{l}661 \\
(3)\end{array}$ & $\begin{array}{l}360 \\
(1)\end{array}$ & 54 & 17 & $\begin{array}{c}12,893 \\
(50)\end{array}$ \\
\hline Average & 5,161 & 878 & 527 & 35 & 23 & 423 & 170 & 167 & 143 & 132 & 72 & 11 & 3 & 2,579 \\
\hline Gyeonggi & $\begin{array}{c}15,302 \\
(100)\end{array}$ & $\begin{array}{c}1,194 \\
(8)\end{array}$ & $\begin{array}{c}2,634 \\
(17)\end{array}$ & 174 & - & - & - & - & - & - & - & - & - & $\begin{array}{c}11,300 \\
(74)\end{array}$ \\
\hline Gangwon & $\begin{array}{l}4,415 \\
(100)\end{array}$ & $\begin{array}{l}482 \\
(11)\end{array}$ & - & - & - & $\begin{array}{c}2,117 \\
(48)\end{array}$ & $\begin{array}{l}371 \\
(8)\end{array}$ & $\begin{array}{l}202 \\
(5)\end{array}$ & $\begin{array}{l}217 \\
(5)\end{array}$ & - & $\begin{array}{l}360 \\
(8)\end{array}$ & - & 14 & $\begin{array}{l}652 \\
(15)\end{array}$ \\
\hline Chungnam & $\begin{array}{l}2,328 \\
(100)\end{array}$ & - & - & - & - & - & $\begin{array}{l}477 \\
(20)\end{array}$ & - & $\begin{array}{l}261 \\
(11)\end{array}$ & $\begin{array}{l}661 \\
(28)\end{array}$ & - & - & - & $\begin{array}{l}929 \\
(40)\end{array}$ \\
\hline Jeonbuk & $\begin{array}{l}1,944 \\
(100)\end{array}$ & $\begin{array}{l}895 \\
(46)\end{array}$ & - & - & $\begin{array}{l}113 \\
(6)\end{array}$ & - & - & $\begin{array}{l}632 \\
(33)\end{array}$ & $\begin{array}{l}235 \\
(12)\end{array}$ & - & - & 54 & 3 & 12 \\
\hline Gyeongnam & $\begin{array}{l}1,817 \\
(100)\end{array}$ & $\begin{array}{l}1,817 \\
(100)\end{array}$ & - & - & - & - & - & - & - & - & - & - & - & - \\
\hline
\end{tabular}

Note: 1. Other of Gyeonggi is earning from lending and use permission.

2. Other of Gangwon is earning from agricultural product sales booths, convenient facilities and ramps to swimming beach.

3. The value in ( ) is the component ratio.

Table 7. Major forest projects of provincial forest

\begin{tabular}{|c|c|c|c|c|c|c|c|c|c|c|c|c|}
\hline \multirow[t]{2}{*}{ Classification } & \multirow{2}{*}{$\begin{array}{l}\text { Forestation } \\
\text { (ha) }\end{array}$} & \multicolumn{7}{|c|}{ Forest maintenance (ha) } & \multicolumn{4}{|c|}{ Forest road (km) } \\
\hline & & Total & $\begin{array}{l}\text { Nurturing } \\
\text { of natural } \\
\text { forest }\end{array}$ & $\begin{array}{c}\text { Improvement } \\
\text { of natural } \\
\text { forest }\end{array}$ & $\begin{array}{c}\text { Harvest } \\
\text { by } \\
\text { thinning }\end{array}$ & $\begin{array}{c}\text { Vine } \\
\text { elimination }\end{array}$ & Mowing & Others & Total & Repairing & $\begin{array}{c}\text { Structure } \\
\text { improvement }\end{array}$ & $\begin{array}{c}\text { New } \\
\text { installation }\end{array}$ \\
\hline Total & 112 & 5,066 & 1,934 & 804 & 495 & 284 & 256 & 1,293 & 69 & 47 & 17 & 5 \\
\hline Average & 22 & 1,013 & 387 & 161 & 99 & 57 & 51 & 259 & 14 & 9 & 3 & 1 \\
\hline Gyeonggi & 20 & 1,000 & 450 & - & 150 & 200 & 130 & 70 & 30 & 26 & 3 & 1 \\
\hline Gangwon & 49 & 1,426 & 284 & 688 & 285 & 34 & 56 & 79 & 24 & 10 & 14 & - \\
\hline Chungnam & 45 & 649 & 400 & 116 & 60 & - & - & 73 & 6 & 4 & - & 2 \\
\hline Jeonbuk & 5 & 990 & 800 & - & - & 50 & 70 & 70 & - & - & - & - \\
\hline Gyeongnam & 6 & 1,000 & - & - & - & - & - & 1,000 & 9 & 7 & - & 2 \\
\hline
\end{tabular}

Note: 1. Others of Gyeonggi refer to nurturing of young trees (70 ha).

2. Others of Gangwon refer to collection of products (73ha) and arrangement in forest (6 ha).

3. Others of Jeonbuk refer to collection of products (70 ha). 
and use permission (Gyeonggi-do Forestry Environment Research Institute, 2009; Kyeonggi-do, 2009; Gangwon-do Forest Development Research Center, 2008; Chungnam Forestry Environment Research Institute, 2009; Jeonbuk Forestry Environment Research Institute, 2009; Gyeongnam Forestry Environment Research Institute, 2009) (Table 6) In addition as the earning from forest products is irregular affected by climate and alternate year bearing, Gangwon had no earning from pine nuts and pine mushroom in 2007.

Major forest projects of provincial forest include forestation, forest maintenance and forest road Among them, the forestation had a business scale of 549 ha, forest maintenance had a scale of 649 1,426 ha averaged to 1,013 ha, but for the forest road, repair and structure improvement took larger part than new installation (Table 7).

\section{CONCLUSION}

1. For the area of provincial forest, it was found that Gyeonggi had the largest area as 31,000 ha, followed by Gangwon with 29,000 ha and Gyeongnam with 16,000 ha Jeonbuk and Chungnam had 11,000 ha of average area respectively For the ratio taken by provincial forest in the whole forest area of the provinces, it was shown that Gyeonggi had the greatest ratio as $5.9 \%$ and the ratio of other 4 provinces was $2.1 \sim 2.5 \%$.

2. It was found that the average forest tree accumulation per ha of nationwide forest was $98 \mathrm{~m}^{3}$ and Gyeongnam had the highest forest tree accumulation per ha as $121 \mathrm{~m}^{3}$, followed by Gyeonggi with $110 \mathrm{~m}^{3}$, Gangwon with $104 \mathrm{~m}^{3}$, and Chungnam with $101 \mathrm{~m}^{3}$.

3. The average revenue of 4 provinces excluding 1,500 million won from selling provincial forest of Chungnam was 92 million won Contents of the revenue consisted of 172 million of forest byproducts, 120 million won of rental income, and 72 million won of collection of province owned forest products.

4. Gangwon had the greatest estimated expenditure as 5,302 million won, followed by Gyeonggi with 4,855 million won, Gyeongnam with 1,582 million won, and Chungnam with 1,397 million won Among the major contents of the expenditure, the forest resource growing was the most as $44 \%$, followed by formation and complement project of leisure facilities with $20 \%$ and basis establishment of provincial forest with $19 \%$.

5. It was shown that their total number of cases relating to lending and use permission of national forest (including profit-sharing forest) was 11,793 and common, public, and industry purpose took their major part The total number of use permission was 713 and its average number of each province was 143 For the contents of permission, it was found that military installation and steel tower in Gyeonggi, common and public and industry in Gangwon, residence and farming in Chungnam, and collection of forest products and farming in Jeonbuk took relatively larger part, suggesting there were some differ- ences in the contents of permission by regions.

6. Although the area of lending and use permission of national forest accounted for $4.5 \%$ of total area of national forest, 1,509,163 ha, it accounted for 3.3\% of the total area of provincial forest of the subjected 5 provinces, 97,000 ha.

7. Total earning of the targeted 5 provinces was 258.06 million won, the average earning of each province was 51.61 million won, and Gyeonggi had the largest earning as 153.02 million won The earning levels of other 4 provinces were in 18.17 44.15 million won However, the average earning of the 5 provinces from their provincial property was 51.61 million won, which was very low level, accounting for $1.8 \%$ of the average annual expenditure of 5 provinces, 2,838 million won.

8. Major forest projects of provincial forest include forestation, forest maintenance and forest road Among them, the forestation had a business scale of $5 \sim 49$ ha, forest maintenance had a scale of 649 1,426 ha averaged to 1,013 ha, but for the forest road, repair and structure improvement took larger part than new installation.

Therefore, it seems that following measures should be sought for healthy fostering and management activation of provincial forest in future.

1. It is considered that although about half of expenditure is currently invested to fostering of forest resources and formation of management basis, it should be managed and operated to be a model of private forest management through continuous investment in future.

2. Considering that status of lending and use permission of provincial forest is lower compared with national forest, it is considered that the lending and use permission of provincial forest to the local residents should be expanded to contribute to increase family income of residents in agricultural and mountain villages as well as activation of local economy and it is considered to be desired that the lending and permission should be expanded gradually from crops in forest causing little damage to the trees and forest In addition, it seems desirable to give a lending and use permission to rural villages or local farming groups rather than individuals to acknowledge contribution of residents who helped to protect provincial forest.

3. Although the management goal of provincial forest may have some differences from other general private forest, it seems also necessary to seek measures to secure the revenue, which is much lower than the estimated expenditure, by actively marketing the thinned wood and by products for expansion of forest commencement Furthermore, it is considered that reviewing measures to invest financial resourced prepared by introduction of systems such as profit sharing contract against provincial residents to forest commencement will be necessary.

4. Finally, in order to suggest developmental measures 
for provincial forest of each province concretely it seems that analysis on multilateral aspects such as forest type, long term management goal, and environmental conditions by provincial forests is essential.

\section{REFERENCES}

Chungnam Forestry Environment Research Institute. 20092009 Major references

Eun-Jin Jeon. 2002 Development of forest administration system for public forest by using GIS technique. National Forest Cooperative Federation. Forest February

Forest Service. 2008a Statistical Yearbook of Forestry

Forest Service. 2008b Study report on technology development for increasing yield of pine nuts

Gangwon-do Forest Development Research Center. 2008 Work Statistic Data

Gyeonggi-do Forestry Environment Research Institute. 2008 Status of permissions for using provincial property (Overall)
Gyeonggi-do Forestry Environment Research Institute. 2009 2009 General conditions

Gyeongnam Forestry Environment Research Institute. 2009 Basic conditions of provincial forest

Jeonbuk Forestry Environment Research Institute. 2009 Promotion plan of major projects in 2009

Jeonbuk Forestry Environment Research Institute. 2009 Contents of work promotion for administration (management) of provincial forest

Kyeonggi-do. 20092009 Forest green zone policies

Sun-Deok Kwon. 2008 Drawing up of forest function classification diagram of public forest. National Forest Cooperative Federation, Forest January

Sun-Deok Kwon et al. 2008 Forest function assessment in basin unit considering distribution pattern of public forest. Journal of Korean Forest Society, 97(1): 71-76

Tae-Sik Park et al. 1987a Study on economic efficiency analysis of White pine within Gyeonggi provincial forest and periodicity of pine nut seeds. Korean Forest Society. Abstracts of Papers, 76(1): 71

Tae-Sik Park et al. 1987b Study on economic utilization of oaks (Against Gyeonggi provincial forest) Korean Forest Society. Abstracts of Papers, 76(1): 71 